\title{
SOUTH AFRICAN ELITES AND CHRISTIAN ETHICS (I) \\ - PERSONAL ETHICS
}

\author{
J Kinghorn, HJ Kotze
}

University of Stellenbosch

\begin{abstract}
South Africa is generally seen as a country in which religious values play a significant role, particularly Christian values. Such statements are, however, extremely difficult to qualify adequately. In this article the results from a national survey among elites conducted in both 1994 and 1995 are employed to gain some insight into the role the Christian faith plays with regard to ethical issues in the process of policy-making in South Africa. The article is a presentation of data which may contribute to a better understanding of the influence of Christian norms and beliefs in the area of personal ethics, whereas civil and social issues are dealt with in a following article.
\end{abstract}

\section{Introduction}

It is one of the truisms of South African popular opinion and scholarship that this society is thoroughly religious. It is also accepted without serious doubt that religion (whichever way it is defined) plays a significant role in value formation, public strategies and power relations. And it is generally assumed that the Christian religion is the major religious influence in private and public life in South Africa.

None of the above has ever been experimentally tested or substantiated beyond mere statements of belief. Many reasons can be advanced for this state of affairs but the most obvious is the serious lack of empirical evidence.

The Longitudinal Study of the South African Elite and their Attitudes regarding Political Change ${ }^{l}$ done at Stellenbosch under the supervision of the department of Political Science, for the first time provides researchers with empirical data substantial enough to attempt a more sophisticated understanding of the religious factor in our public life.

This paper draws on the data collected during 1994 and 1995. In particular the focus is on the nexus between religion, values and social behaviour. As Southern African academic and social discourse has been dominated for decades by ideological posturing and propaganda a thorough analysis of prevailing values is in short supply. Undoubtedly religion is one of and perhaps the main bearer of values. The relevance of incisive research in this area is, therefore, evident.

Useful as it is, the data drawn upon does not allow incontestable conclusions though. At best it provides one with a better foothold on the way to the top but not with a panoramic view. It is, therefore, not the purpose of this article to develop comprehensive theories on the basis of the available data. For now the publication of the results of the survey will have to suffice.

The graphs are, therefore, largely self explanatory.

1 This is a positional elites study. HJ Kotzé argues that "... elites are the societal agents through which broader forces such as etnicity, class, religion, etc. are filtered to ordinary people; elites give predictable thrust to the functioning of political regimes; ... elites... are indeed the 'switchmen of history'....The operational definition of elites for the purposes of the survey is "those persons who hold authoritative positions in powerful public and private organisations and influential movements, and who are therefore able to affect strategic decisions regularly". (Research Report No 3 of 1992, p 17.

Centre for International and Comparative Politics: Stellenbosch) 


\section{The nature of the sample}

It comes as no surprise that the sample of elites show a bias toward the Afrikaans community in general and, therefore, the traditional Reformed Christian Church traditions in particular. Nevertheless, the overall sample is big enough to allow a grouping of the data into four distinct categories, yielding useful comparative material.

The groups were categorised as follows: Afrikaans Mainline consists of the Dutch Reformed Church, Dutch Reformed Mission Church, Reformed Church, Afrikaanse Protestantse Kerk and the Hervormde Kerk. The English Mainline churches comprise: the Anglican Church (including variants), Methodist Church, Congregational Church, Lutheran Church, Baptist Church, Roman Catholic. The non-religious category consists of those who either expressed opposition to religion, a preference for atheism or merely indifference. Finally the non-mainline group are those who do not fall into any one of the above categories. This group includes, for example, various Pentecostal movements and indigenous churches.

The overall ratio of the four groups did not vary from 1994 to 1995. As neither ethical norms in general nor ethical principles held by individuals change easily it is, therefore, acceptable to use the data from the two surveys interchangeably.

\section{Overall comments}

One of the rather surprising findings is that the gap between religious and non-religious people (at least in the elites group) is small. When asked specifically religious questions, such as whether a transcendent Being exists, the differences are noticeable. And the majority by far of the non-religious group do not think that their religious views have any bearing on other areas of their life.

But once the focus shifts away from overtly religious questions the mores and attitudes seem to converge most of the time. When divergence shows up, it can often be ascribed to factors other than overt Christian ethical concerns. The measure of "sympathy" toward the SACC is a good illustration. In this particular case the Afrikaans mainline church members show a distinct dislike in the Council, whereas the other three groups follow the same pattern of a rather even spread between likes and dislikes. It must be assumed that the divergence of the Afrikaans mainline church members in this case is politically motivated.

This trend is carried through in most of the questions put in the questionnaire. All such questions have, therefore, been bypassed for the purposes of this article. Only questions which can not be (adequately) explained on the basis of pure political and economic preferences were taken into account.

The results of responses to such questions are graphically presented under the titles: Death Penalty?; the theory of evolution?; Abortion?; Pre-marital sex?; Strict discipline?; Legalise dagga smoking?

Two aspects are noticeable. Firstly, the non-religious are generally slightly more inclined to liberal attitudes with regard to individual ethics. This not necessarily means that the individuals who responded to the questionnaire positively support, for instance, dagga smoking. But it is clear that they espouse a more lenient attitude toward the preferences of other people than do the church groups. That there is very little difference in this respect between the various church traditions is quite evident from the responses to the question concerning strict discipline.

The second observation is that the mainline Afrikaans and the non-mainline Churches seem to reflect a similar ethical category, at least when intimate, personal ethics is concerned. This is emphasised by the patterns of responses to the questions on the theory of evolution, abortion and premarital sex. It is also reflected in the responses to the question on strict discipline. 


\section{SAMPLE ACCORDING TO \\ CHURCH AFFILIATION}

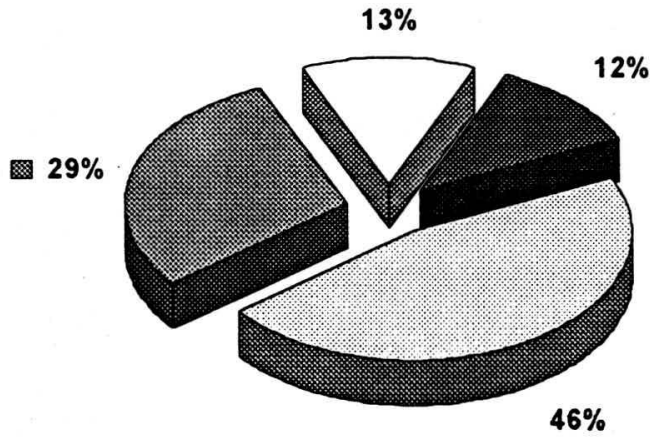

AFR. Mainline ENG. Mainline $\square$ Non-Mainline

Non Religious

Source Stellenbusch Elites Survey 199

PERCEPTIONS OF GOD

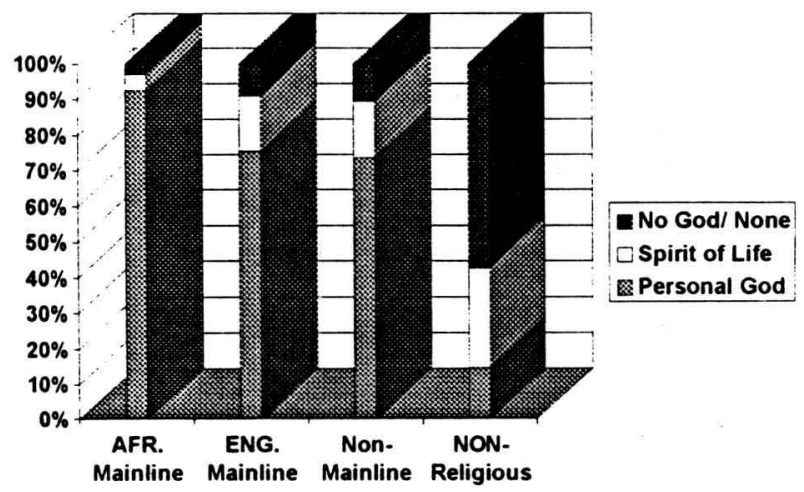

Source: Stellenbosch Elites Survey 1994 
Statement: My religious convictions have a definite influence on my views on other areas of

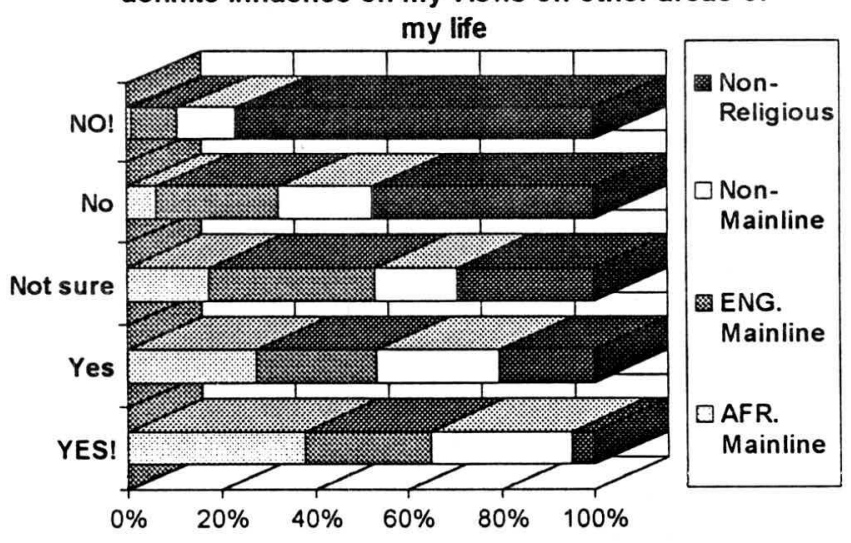

Source Stellenbosch Elites Sunvey 1994

Sympathy toward the SA Council of Churches

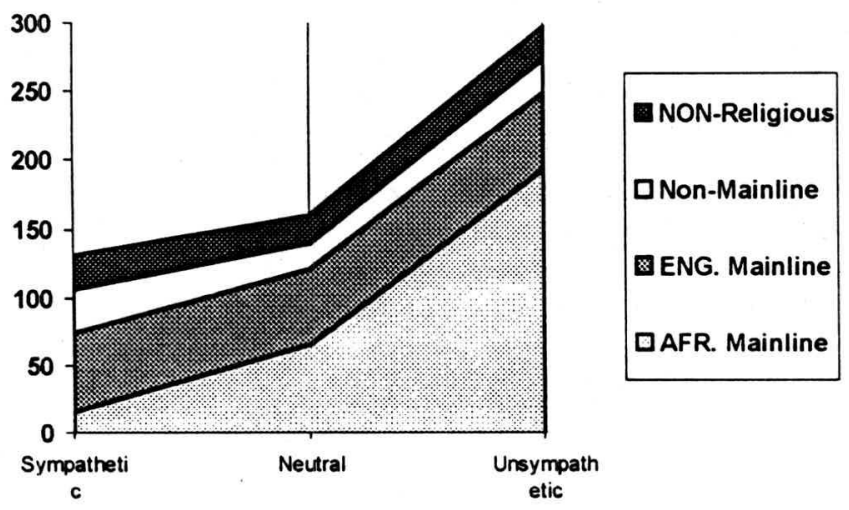



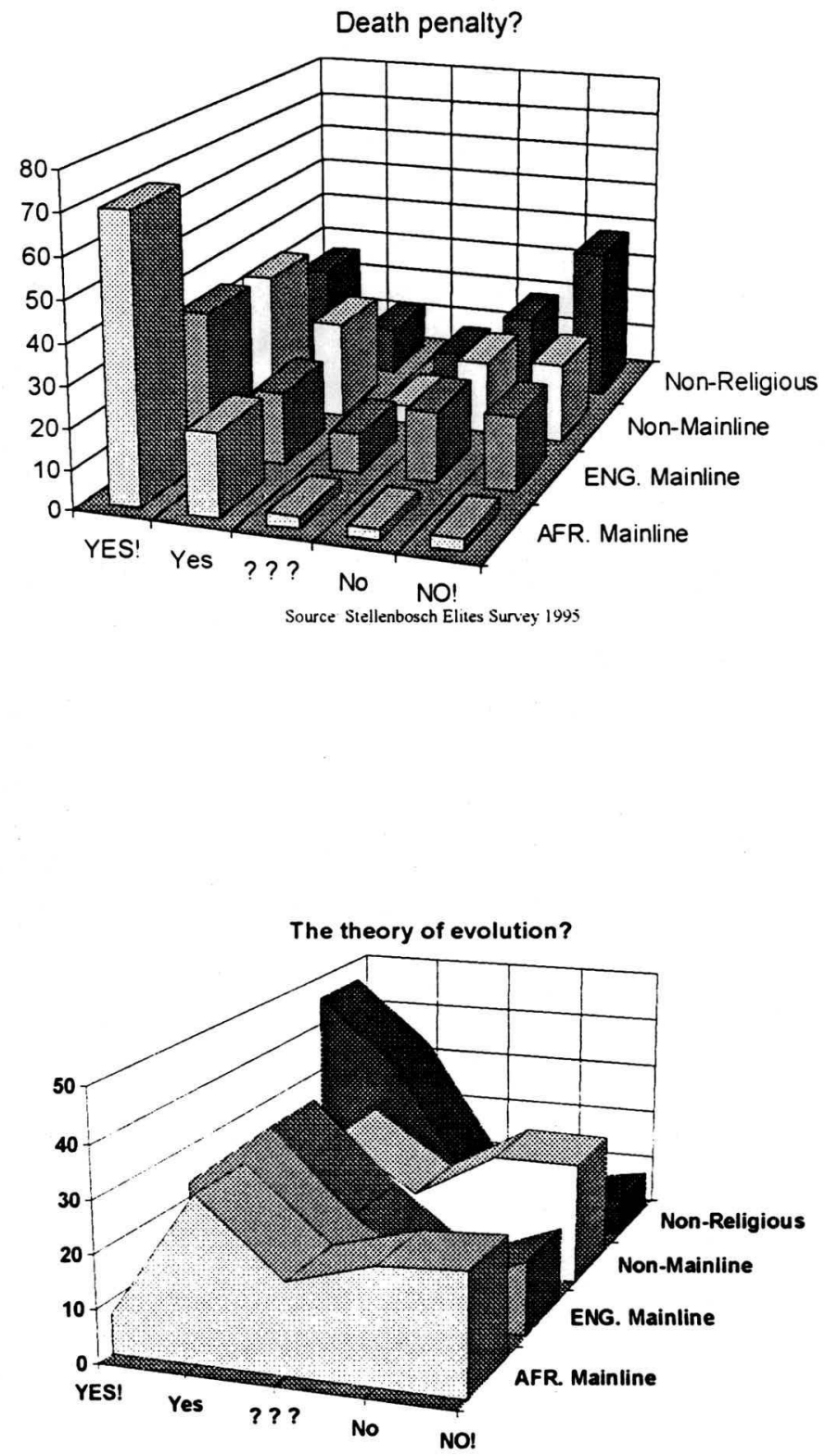

Suurce Stelienbusch Eiltes Survev 19y5 


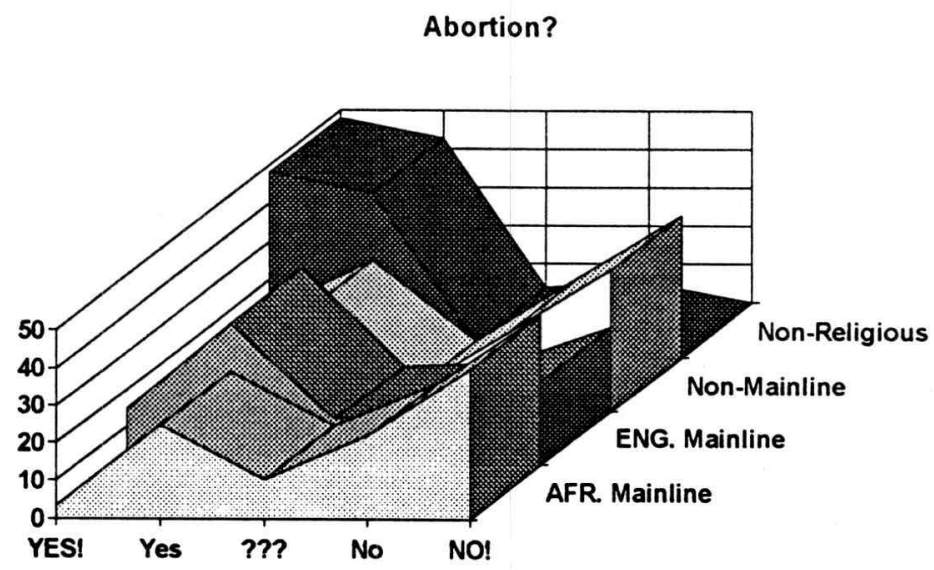

Source: Stellenbosch Elites Survev 1995

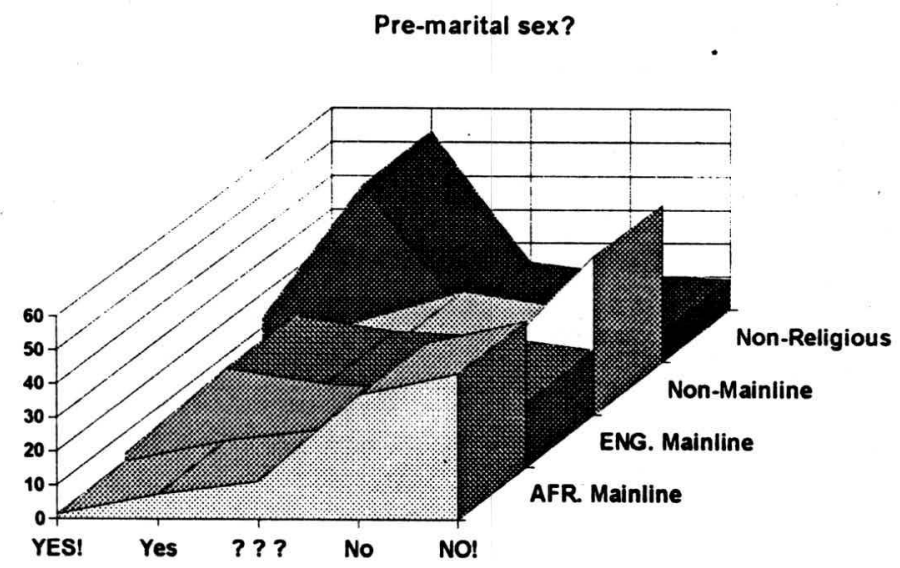

Source Steilenbosch Elites Survey 1995 


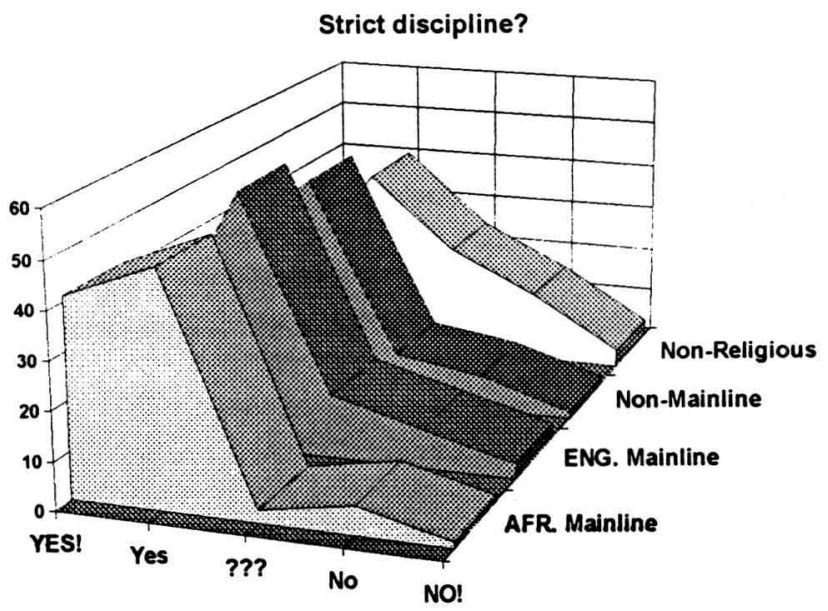

Source Stellenbosch Elites Sunev 1995

Legalise dagga smoking?

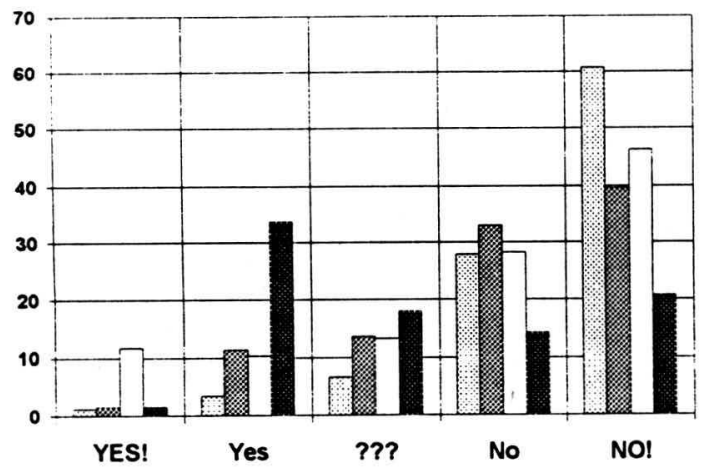

슨.

Mainline

쯜. ENG.

Mainline

$\square$ Non-

Mainline

플 Non-

Religious:

Source Stellenbosch Elites Suncy 1995 